\title{
Intersexuality and the Subjective Definition of Gender
}

\author{
Ana Amélia Reis de Paula, Márcia Maria Rosa Vieira \\ Sebastião Maciel Reis/Lélia de Oliveira Reis, Belo Horizonte, Brazil \\ Email: anamelia27@gmail.com, marcia.rosa@globo.com
}

Received 28 April 2014; revised 24 May 2014; accepted 18 June 2014

Copyright (C) 2014 by authors and Scientific Research Publishing Inc.

This work is licensed under the Creative Commons Attribution International License (CC BY). http://creativecommons.org/licenses/by/4.0/

(c) (i) Open Access

\section{Abstract}

Intersexuality questions how human gender definition occurs. As a baby is born, a sex, boy or girl, is assigned through genital observation. However, the simplicity to assign the gender disappears when, as the genitals are observed, their conformation is not clear. Genitals are ambiguous when their appearance imposes difficulties, or even an impossibility to assign a sex to a child. This is the case for children born with some degree of deformity or any Sexual Differentiation Disorders (SDD). Such fact places a strain, both on the parents and on those who will assist the child. The complexity of the problem demands that the child be assisted by an interdisciplinary team composed of a pediatrician, an endocrinologist, a surgeon and a psychologist in addition to a team of diagnostics experts. A study is undertaken in order to understand what caused the Genital Ambiguity (GA) and, therefore, make sex definition possible. When the SDD diagnosis is established early in life, it can cause severe angst on the parents or even the family. That is because it is the family who will be held responsible for what happens to the child. The name choice and the civil registry is the parents' responsibility. They must make a choice. The parents decide if there will be an investigation in order to make the biological sex clear, or if they will allow the child to grow so that they can define their own sex, based on the assumption that nature itself may decide the path towards sexual clarity. Although possible, that is a perilous path to follow, since biology has already given hints that something has happened that prevented the sexual identification already at birth. The article deals with the main discoveries and psychoanalytic concepts in relation to sexual constitution and its workings in order to clarify the question that has guided and accompanied us along the way: does sexual ambiguity interfere in the assumption of sex made by the subject? Clinical medicine teaches us how the subjects have answered the question: Am I a boy or a girl?

\section{Keywords}

Genital Ambiguity, Intersexuality, Gender Identity, Psychoanalysis 


\section{When the Body Isn't a Guide/Doesn't Serve as a Guide}

Genital malformation prevents sexual identification at birth. Intersexuality is the term used to describe such cases. Hermafroditism is the coexistence of ovarian tissue (with follicles) and testicular tissue (with seminal tubes, with or without sperm) in the same individual, usually associated to internal and external Genital Ambiguity in various degrees. Nowadays, Sexual Differentiation Disorders (SDD) is the preferred medical terminology.

When the body is not able to guide the definition of the baby as a boy or a girl, how does the subject make (or not) their sex choice? In order to answer them it is important to know the part played by anatomy in sexual constitution and what process the subject goes through to realize the assumption of its sex.

Distinguishing genital ambiguity (GA) from sexual ambiguity is essential to those who work in the treatment of SDD. What is genital ambiguity? What does gender ambiguity consist of? What is its field? Is treating genital ambiguity the same as treating sexual ambiguity? Does the presence of GA mean there is, necessarily, sexual ambiguity? In his text "The development of the sexual function", Freud clearly presents this distinction:

It is necessary to distinguish sharply between the concepts of "sexual" and "genital". The former is the wider concept and includes many activities that have nothing to do with the genitals. ( $\cdots$ ) Sexual life includes the function of obtaining pleasure from zones of the body-a function that is subsequently brought into the service of reproduction. The two functions often fail to coincide completely (Freud, [1937-1939] 1976).

Therefore, GA is a biological problem: the difficulty in distinguishing the sexes’ anatomical differences taking the genitals as a basis, in other words, “( $\cdots)$ we can say that genitals are ambiguous every time it presents the doctor with the difficulty to assign a gender to a child” (Damiani, D. \& Steinmetz, L., 2010: p. 78). Gender ambiguity refers to the adversities of sexual choice, achieved in more comprehensive process, involving a group of elements that goes beyond the discussion on genitality. GA belongs to the scope of Biology and Medicine. Sexual ambiguity should be analyzed within the scope of studies that take into account the processes involved in sexual identification, subjective constitution and subjectification process. GA involves psychic processes that influence how the individual subjectively perceives a biological event such as GA. That is precisely the epistemological field of psychoanalytic research.

GA may be diagnosed right at the beginning of life. When it happens, the problem is presented to the mother at the beginning of the baby's life. She is the first subject that, before the child itself, has to deal with the issue. GA brings about the issue of chance and temporality. It may or it may not be diagnosed at the beginning of the child's life. Therefore, the child is subject to chance because they depend on the one from whom they receive their first care. This is a decisive moment and it has consequences due to the fact that a baby does not have the necessary resources to satisfy its own vital needs. This condition of inability to satisfy oneself, with which the human organism is born, is called by Freud ([1895] 1950) "initial helplessness" (anfängliche Hilflosigkeit). The experience of satisfaction can only be achieved if, by chance, there is an outside intervention from the external world that promotes a specific action. This action is a task performed by an experienced person that responds to the baby's scream. Thus, it is precisely the initial helplessness that will ultimately introduce the baby to a world of relationships: "this path of discharge [the scream] acquires a secondary function of the highest importance, that of communication, and the initial helplessness of human beings is the primal source of all moral motives” (Freud, 1950 [1895]: p. 431). The baby's vital needs, at first, are signaled by it through a discharge. The mother or the person that embraces that discharge-that arises as a scream-interprets that the baby experiences something: pain, hunger, thirst, cold, discomfort, sleepiness, etc. The mother will have to translate what the baby needs. Lacan revisits this primal relationship between mother and child and sees in it the issue of desire.

$(\cdots)$ the relationship between child and mother, as far as the child reveals to depend on the mother's desire, from the first symbolization of the mother as such, and on nothing other than that. Through this symbolization, the child detaches its effective dependence on the mother's desire from the pure and simple living experience of that dependence and something is instituted which is subjectified at a first, primordial level. (Lacan, 1999: p. 188).

We have here something essential: the relationship between the child and the mother begins supported by the satisfaction of biological needs, such as hunger and pain. With the mother's interference, this primordial being, something beyond pure and simple nutrition is engendered. Thus, the mother offers, not only the object for sa- 
tisfaction of needs, but also another one, she also offers herself as a being of desire. According to Freud (Freud, 1905: p. 132) the causes of the problems connected to sexuality should not be sought neither in the innate nor in the acquired, but they should be investigated in the individual; therefore in the subjectivity.

It is virtually impossible to keep the child ignorant about their sexual life. In the same way, the clinical medicine of SDD shows that is impossible to keep the issue of GA unknown to the children. They will try to find out the reasons that make them see the doctor periodically. Why does the doctor need to observe, measure and examine precisely their genitalia? Why take medicine everyday? Or, the moment they compare themselves with another child, they are sure to ask why their genitals are not the same as their little brother or why it does not look like their girlfriend's.

In the text "On the Sexual Theories of Children", Freud (1908a) is surprised to discover that the difference between the sexes does not constitute, at first, the children's first interest of investigation. He explains: "the fact that there are two sexes amongst human beings, although very similar in other aspects, with their difference displayed through obvious external signs, that is not the child's first interest on sexual problems.” (Freud, 1908: p. 215). The child's interest to investigate the issue of the difference between the genders does not come up spontaneously. The child finds itself forced to research in consequence to a practical situation they have lived, such as a baby's birth. The child feels threatened with losing the love or the attention from the parents. To Freud, "the first great problem in life" the child will face is "where do babies come from?” (Freud, 1908: p. 215). The children do not realize from the start the anatomical difference of the sexes or, somehow, there is a delay in taking that matter as an issue to investigate. Such fact, discovered in Freud's studies is not without reason.

In what way do children do their research? They will ask people they trust: those they admire. Freud declares that, "if the child was not overly intimidated, sooner or later they will resort to the direct method of demanding an answer from the parents or from the caretakers, who represent, in their eyes, the source of all knowledge". (1908b: p. 216). If the child is not intimidated or repressed in their manifestations of curiosity, they will be able to directly approach the parents about their doubts.

To answer the question about the origin of babies and about other issues regarding sex that arise to the child, Freud states: children formulate theories. They construct "mistaken sexual theories", that are devised as follows:

The part of those theories that is correct and reaches the target derive from the sexual drive that already operates on the child's body. It does not arise from an arbitrary mental action or from casual impressions, but from the child's psychosexual development constitution, the reason why we can talk about typical sexual theories (Freud, 1908b: pp. 218-219).

The anatomical difference between the sexes remains ignored as it prevails, at this moment, a typical infantile sexual theory, the one that attributes to all beings, even inanimate ones, possession of a penis: the boy assumes that genitals like his would be present on all people he knows, and it is not possible to imagine otherwise.” (Freud, 1905: p. 183). This moment of the child's sexual constitution is called by Freud phallic stage. The conviction underpinned by the boy will be defended energetically when he is faced with reality. The phallic stage is true also for the girls. Freud comes to the conclusion that children from both sexes formulate the theory that, originally, everyone possesses a phallus.

The moment of discovery that there are beings which do not possess the organ is called castration complex, since the female gender remains ignored, unknown. According to the child's fantasy, the belief that one has or does not have the phallus remains. The reference is still the male sex. The theory undergoes a small modification when the child is faced with the difference between the sexes: now, not everyone possesses the penis, some people have been castrated. However, it is assumed the mother still has a phallus. Only with the revelation that it is the women who can have babies, children begin to suspect that their mothers also do not have an organ. However, the female genitals remain unknown. Children's sexual theories govern their sexual organization in such a way that the knowledge of the biological science that the clitoris may be "an authentic substitute for the penis" has no use for them (Freud, 1905: p. 183). In the prepubertal phase, the final years of childhood, is when we find a greater production of sexual theories. It is the moment when the child is most invested in their research on sexuality. "Children's sexual theories are reflections of the child's own sexual constitution" (Freud, 1905: p. 184). What would the sexual constitution of the child mentioned by Freud be, whose sexual theories are its reflection? The child's sexual constitution arises supported by the biological needs, such as the suckling of the infant, for instance. The biological functions are lessened through the action of language; a change from instinct to pulsion is the process of subjectification that happens in the mother-baby relationship. In childhood, according 
to the infantile fantasy, all children would be boys and that is because both sexes believe to have a phallus. A path that leads to the discovery of the anatomical difference between the sexes is needed so that, both boy and girl, can reach their sexual identification. Such path goes through what Freud named Oedipus complex, the moment when children establish fundamental relationships with the parental pair, for being libidinously invested on those who are their first objects. At the same time the child experiences feelings originated in their own body that are incomprehensible; also, at this moment, children discover the anatomical difference between the sexes. They are forced to construct theories that can explain such events. The observation of the infantile sexual theories led Freud to formalize his findings in what he called phallic stage and castration complex.

On the other hand, the choice of sexual object happens in two stages, "in two waves", in Freud's words (1905: p. 187). The first wave, the first moment, of the human sexual life in which the child makes the first approach on the one who will be their sexual object, happens from two to five years of age. The sexual investigation process backtracks around the fifth year of age due to psychological repression. Psychological repression is a force that holds back the child's interest in investigating the theme of sexuality; it shifts their attention to other issues that are not exclusively sexual. The latency period begins, in which there is retention of the sexual investigations, but not their annihilation. The second wave is the moment of awakening of sexuality that happens with puberty. It is the sexual life decisive moment. Bitemporality, as Freud states,

$(\cdots)$ is of paramount importance to the disarray of the final state. That is because the choice of object made in the early childhood may continue throughout the subject's life or can, later on, be reviewed during puberty (Freud, 1905: p. 188).

Puberty brings along changes that lead the child's sexual life to its definite configuration. It is in puberty that a new sexual target arises. Freud verifies that there is an important difference when it comes to girls in relation to the Oedipus's processes and the castration complex. This way, he is forced to question: if the mother is the first object of love to both sexes what is it that causes the girl to turn away from her? He eventually finds out there was "an interesting contrast between both sexes' behaviors" (Freud, 1925: p. 313). This difference is related to how each one will react in discovering the anatomical distinction between the sexes. As the boy realizes this difference he demonstrates "irresolution or lack of interest; he does not see anything or he rejects what he saw, softens his expression or searches for manners to adjust it to his expectations" (Freud, 1925: p. 313). Later on, when confronted with the threat of castration, the observation becomes important to him. The girl has a rather different behavior; she admits not to have the phallus. Through anatomical comparison, her judgment on the matter is quick and her decision is made. "She has seen it, knows she does not have it, but wants to." (Freud, 1925: p. 313). We find here the importance of the anatomical observation, since the girl reacts differently from the boy. She knows she does not have it. She realizes, based on her own body, that she does not have it, at the moment she makes the comparison. This event does not happen in isolation, it is influenced by another event. Freud states the existence of a pre-history to the Oedipus complex for the girls and calls it "secondary formation”, (1925: p. 314) a stage that comprehends the period of time she remains connected to the mother.

We should highlight the three findings of psychoanalytic theory essential to our investigation of genital ambiguity:

1) There is a difference between boys' and girls' sexual developments.

2) This difference is due to the anatomical distinction between the sexes, which children are bound to find during their path to sexual constitution. The distinction made by the children includes the comparison of their genital organs to the others'. It is the moment of discovery of the anatomical difference between the sexes. This perception does not happen in isolation, it receives influences from something the child experiences in their own body, but it is not possible for them to give meaning to these experiences.

The child's first genital sensations are disturbing to the point they become, to them, neither identifiable nor easy to locate. The genitals, that evade all forms of control, may actually seem to them to be outside her body. Language is then summoned to interpret these first experiences: that results in interesting elaborations of knowledge, the "infantile sexual theories" (Morel, 2000: pp. 26-27).

3) The discovery of the difference between the sexes is connected to the "psychic situation involved in it" (Freud, 1925): the child's experience of the Oedipus complex, the phallic phase and the castration complex.

There is a biological data, an element of reality at stake, which relates to whether or not the child has a penis. There is another vital element that refers to the psychic situation experienced in this constitutive moment: the 
child's relationship to the parental pair. The child counts on their body and on the psychic situation that concerns the relationship with the parents as elements that participate in the sexual identity process. In what way does this moment take place for a child that cannot carry out the comparison of genitals given that their own genitals are ambiguous?

In R.'s case, the child was determined, biologically, a female. However, her virilization caused the mother to identify her in the male side. In this case, anatomy continued to lead the way. R. identifies herself in the male side. However, how would the definition happen in the rare cases of true hermaphroditism in which there is no possibility of sex definition through anatomy, nor through gonadal investigation due to the presence of gonads from both sexes? Let us turn to clinical medicine.

A five-year old child arrives accompanied by their mother to have their sex investigated. It was true hermaphroditism and in that case an anatomical examination did not allow sex distinction and imaging examination revealed traces of rudimentary organs, both male and female, in the abdominal cavity. The physician's approach was that the most feasible course of action would be to raise the child a female. When puberty was reached the child would have their secondary sexual characters developed through the use of hormones. However, the child had been registered with a male name, $\mathrm{M}$. According to the mother she had given the child a temporary name so that the child could have a social life. She points out that she never hid from her son what was happening. She had told him his genitals were not totally formed, and he needed medical help. The child reports to be the second son, to have an older brother and a younger one. In his family there were only men. The mother arrives with the child and does not hide her expectations that the doctors found out that he was, actually, a girl. In our first meeting the child reported to be worried about the test results for being afraid to be assigned male. The child clearly states to want to be a girl. Why do you wish to be a girl? "There are only men in my family and I want to be the girl my mom did not have!”

In this case, the biological data could not define the sex, which is called mosaicism. The child is examined by doctors and referred to a psychoanalyst to verify if there was an established sexual identity.

The child narrates how they believed to be a girl, even though they received a masculine name and dressed as a male. The child states to have realized since a very early age that they liked to play with girly things and really wanted to look like their mother; M. confesses playing make-up with the mother and believed in the possibility of coming to find out that they were actually a girl.

This case sends us back to the question posed by R.: "Can wishing be stronger than the body?” The case answers affirmatively. What defined M.'s sex was not the genitals, nor the clothing, nor the child's own name, but the maternal wish to have a girl, which was transmitted to the child. That is where, the place of "the girl my mother did not have", that the child will identify themselves. The child chooses their new name, which refers to the M. character: meaning they assign to the indefinition period. With the sex she always knew to belong to, M. begins her school life.

Freud (1933 [1932]) states in his text on "Femininity": "When you meet a human being, the first distinction you make is [whether they are] 'male or female?'. And you are accustomed to make that distinction with unhesitating certainty." (p. 141). This distinction between sexes is made through the anatomical difference and the secondary sexual characters. At this point Freud makes reference to the rare cases of hermaphroditism that do not allow such distinction since they present characteristics from both sexes. These considerations are made at a first moment so that he can introduce another important distinction. The author states that there is a difference between the sexes influenced by the body, perceived through anatomical observation. However, there is another distinction pertaining to our investigation. Freud (1933 [1934]) states: “( $\cdots)$ that which constitutes either masculinity or femininity is an unknown characteristic which anatomy cannot lay hold of.” (p. 141). In the search for definitions for both masculinity and femininity, to Freud, masculine is what is connected to action and aggressiveness; and femininity to passiveness. However, these approximations are inefficient in handling such concepts. It is easily perceptible the adaptation and passiveness in men's lives and a lot of action in women's. Freud concludes (1933 [1932]) that femininity is an enigma. Therefore, on the one hand, Freud says it is not under the scope of psychoanalysis to describe what the woman is. That, according to him, would be a task it could scarcely perform. On the other hand, "psychoanalysis sets about enquiring how she comes into being, how a woman develops out of a child with a bisexual disposition." (Freud, 1933 [1932]). We must remember what happens at the phallic stage: “( $\cdots)$ at the phallic stage the differences between the sexes are completely eclipsed by their agreements. We are now obliged to recognize that the little girl is a little man.” (Freud, 1933 [1932]: p. 145). Following the Freudian approach on the child's sexual constitution, there is the bisexuality from where the sex- 
ual development begins until the differentiation in boy and girl. This bisexuality undergoes anatomical comparison and difficulties of Oedipus complex, which results in the child's identification with the father or the mother. The discovery of the anatomical differences between the sexes brings consequences to the forming sexuality and also in the already formed sexuality in adult life. Such discovery happens simultaneously to the Oedipus complex, that is, the child is affectionately connected to the parents and that is what actually interferes in the way the child will overcome the complex. The overcoming of the Oedipus complex is characterized by the sexual identification. The boys identify with the one with the phallus and the girls recognize they don't have it and direct their attention to the one who has it.

In the case of children with GA it is possible to distinguish two situations of bisexuality: anatomical and psychic. In M.’s case, psychoanalytical listening revealed there was not, in the subject's viewpoint, any doubt as to their sexual identity. The subject declares that they know what their sex was: female. She resorts to medical science so that its resources may treat the genital ambiguity. This differentiation, made by Freud at this point, in relation to anatomical distinction on the one hand, and on the other the concept of what either masculinity or femininity might be; precisely at this moment Freud (1933 [1932]) does not indicate bisexuality or the identifications as solutions, he points at pulsion: "the differences are highlighted also in the pulsion disposition that allows a glimpse into the ensuing nature of women” (p. 145). This line of investigation on pulsion begins to distance him from those characteristics linked to the anatomical difference or those connected to biology. There is a Freudian suspicion that there would be a different way of pulsional satisfaction between men and women. The research progress with Lacan, in his sexuation table and with the concept of jouissance, will allow him to differentiate men from women from a viewpoint related to the manner of pulsional satisfaction, in lacanian terms, in relation to ways of reaching jouissance.

The objective of sex determination at the beginning of life is to facilitate the child's access to the social context or to provide them with elements that guide them in their own psychic constitution at the moment of identification or choice of sex. Clinical medicine shows there are disastrous results in the case of children who found isolation and problems at school, among other symptoms, as a way out, for not having been able to answer the question: "am I a boy or a girl?"

Maciel-Guerra and Guerra Junior (2010) state that "with either a newborn with genital ambiguity or a teenager with delayed puberty or heterosexual pubertal characteristics, there is a great psychological impact on the families.” (p.451). It is necessary to clarify what this psychological impact on the families, identified by the authors, is. Indeed, the reference to the psychological brings into play the parents and the afflicted children's subjectivity. The parents as well as the children will respond, one way or another, when faced with the issue of GA. Consequently, the presence of the psychologist in the interdisciplinary team must go beyond assisting and responding to various medical demands. Undoubtedly, the main demands are investigating the sexual identity of a child with ambiguous genitalia that is late for treatment, or assisting the parents who have received the news about their baby's diagnosis. However, the psychologist's role, with the psychoanalytic-oriented psychologists in mind, when elucidated, guides when and how their intervention may happen. Indubitably, for those who practice in this field of medicine, it is vital not only to know the psychic constitution and sexual identity processes but also to distinguish the main discourses and concepts involved in this debate.

There are several situations presented by children who suffer from SDD as they require medical and psychological treatment. There are children who, even though having received the diagnosis at birth, return close to puberty, still without a defined identity, either because of ignorance and/or economic limitations. Others only discover the problem later in life, at puberty. The deferred definition has a negative impact on the childhood, on fitting into school and on their love life.

\section{Conclusion}

Freud makes some decisive and fundamental contributions to the field of genital ambiguity. He marks a clear distinction between the notions of genital and sexual. The notion of sexual is broader and it is not limited to genitality. In this way, two fields of clinical action for SDD are defined: the one that treats the genital, which investigates the cause of the genital ambiguity and the modes of treatment. This field is one of medicine. The other field of investigation is the one that refers to the sexuality, the sexual field. This field focuses on investigating the manner in which the subject assumes (or not) their sexual identity and the vicissitudes of this choice. This is the field for psychoanalytical research. Freud offers the indications of where the researches on sexuality should 
be directed by questioning if it is an innate or acquired trait. Regarding this, he declares that it is neither one nor the other. There is "something in the individual" that has to be investigated, and that "something" is subjectivity and it can only be accessed through the word or, in Lacan's terms, by the signifier. Lacan refers to the "other scene" to summon the Freudian discovery of the unconscious. Human sexuality occurs in this other scene, the place that should be investigated.

Freud's declaration that sexuality does not begin at puberty, but that it has clear manifestations in early childhood, immediately after birth, goes against the argument sustained today that intervention does not need to happen at the start of the life given that sexuality happens as product of puberty. This allegation, according to Freud's teachings, is wrong. The debate over the need to intervene or not in the beginning of life should not refer to the question of time, but to the vicissitudes of each case, to the needs and issues the case presents. It is especially imperative to pay attention to a very important element that remains forgotten in this debate: the way sexual definition happens from a subjective constitution. The subjective sexual constitution does not coincide with the biological sexual constitution. These processes are independent and cannot be considered identical. Such considerations are based on the Freudian suggestion to keep a distinction between the notions of genitality and sexual identity.

\section{References}

Freud, S. (1950 [1895]) Projeto para uma Psicologia Científica. In: Publicações Pré-psicanalíticas e Esboços Inéditos (pp. 387-463). Rio de Janeiro: Imago, 1976. (Edição Standard Brasileira das Obras Psicológicas Completas de Sigmund Freud, 1)

Freud, S. (1905). Três Ensaios Sobre a Teoria da Sexualidade. In: Fragmento da Análise de um caso de histeria, Três Ensaios sobre a Teoria da Sexualidade e Outros trabalhos (pp. 118-126). Rio de Janeiro: Imago, 1989. (Edição Standard Brasileira das Obras Psicológicas Completas de Sigmund Freud, 7).

Freud, S. (1908a). O Esclarecimento Sexual das Crianças. In: Gradiva de Jansen e Outros Trabalhos (pp. 135-144). Rio de Janeiro: Imago, 1976. (Edição Standard Brasileira das Obras Psicológicas Completas de Sigmund Freud, 9).

Freud, S. (1908b). Sobre as Teorias Sexuais das Crianças. In: Gradiva de Jansen e Outros Trabalhos (pp. 211-228). Rio de Janeiro: Imago, 1976. (Edição Standard Brasileira das Obras Psicológicas Completas de Sigmund Freud, 9).

Freud, S. (1925). Algumas Conseqüências Psíquicas da Distinção Anatômica entre os Sexos. In: O Ego e o Id Uma neurose demoníaca do século XVII e outros trabalhos (pp. 303-320). Rio de Janeiro: Imago, 1976. (Edição Standard Brasileira das Obras Psicológicas Completas de Sigmund Freud, 19).

Freud, S. (1933). Conferência XXXIII: Feminilidade. In: Novas conferências introdutórias sobre psicanálise (pp. 139-165). Rio de Janeiro: Imago, 1976. (Edição Standard Brasileira das Obras Completas de Sigmund Freud, 22).

Freud, S. (1937-1939). O Desenvolvimento da Função Sexual. In: Moisés e o Monoteísmo Esboço de Psicanálise e Outros Trabalhos (pp. 177-181). Rio de Janeiro: Imago, 1976. (Edição Standard Brasileira das Obras Completas de Sigmund Freud. 23).

Lacan, J. (1999). O Seminário, Livro 5. As formações do inconsciente (1957-1958). Rio de Janeiro: Jorge Zahar Editor, 149-205.

Maciel-Guerra, A. T., \& Guerra Júnior, G. (2010). Menino ou Menina? Distúrbios da Diferenciação do Sexo ( $2^{\mathrm{a}}$ ed.). Rio de Janeiro: Rubio.

Morel, G. (2000). Ambiguités Sexualles Sexuation et Psychose. Paris: Anthropos. 
Scientific Research Publishing (SCIRP) is one of the largest Open Access journal publishers. It is currently publishing more than 200 open access, online, peer-reviewed journals covering a wide range of academic disciplines. SCIRP serves the worldwide academic communities and contributes to the progress and application of science with its publication.

Other selected journals from SCIRP are listed as below. Submit your manuscript to us via either submit@scirp.org or Online Submission Portal.
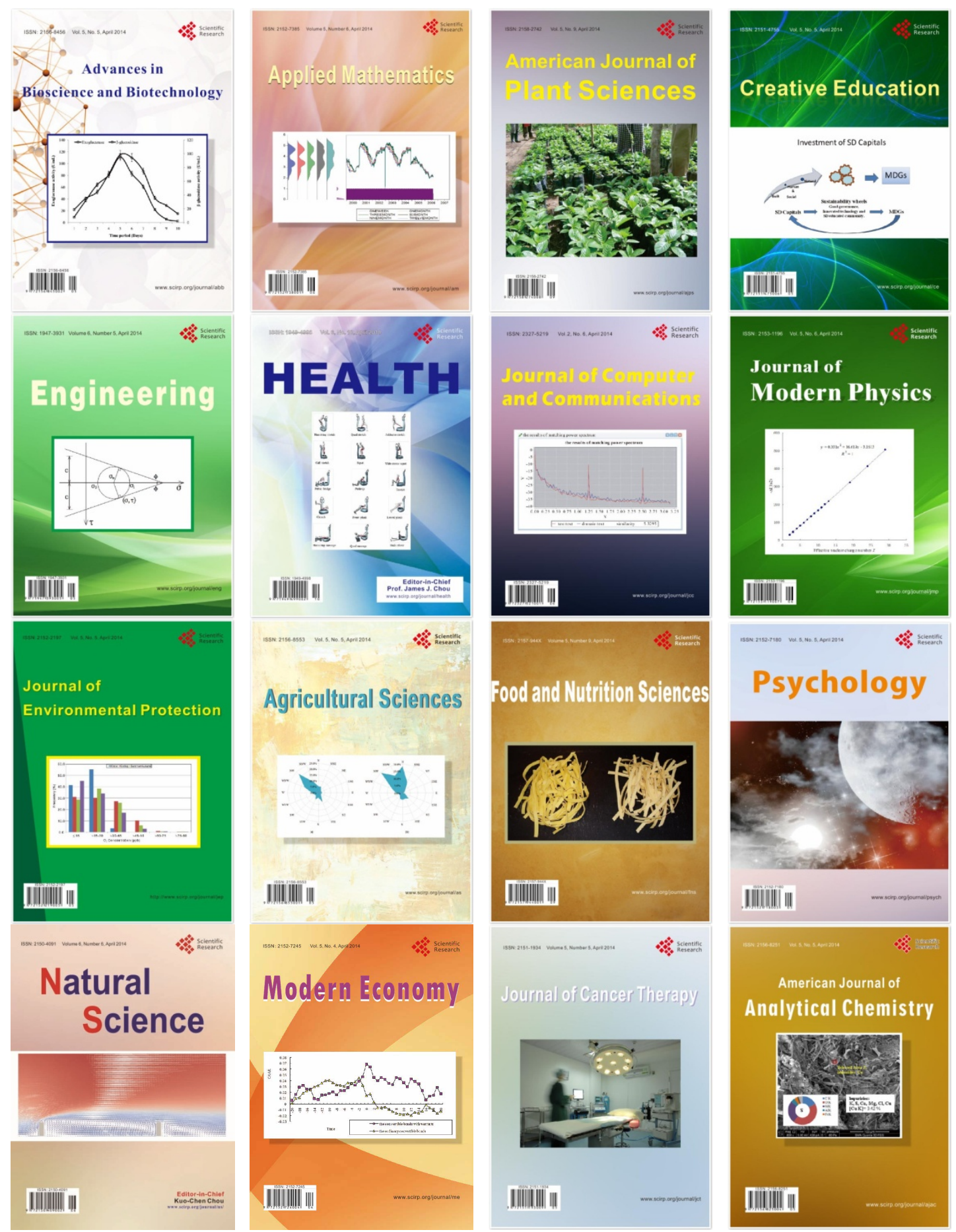